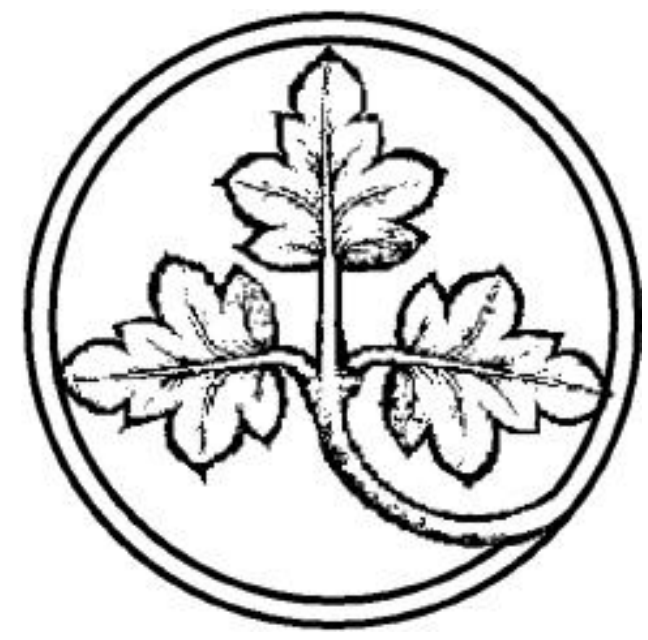

Gemeinschaftsgüter: Recht, Politik und Ökonomie

\author{
Preprints \\ aus der Max-Planck-Projektgruppe \\ Recht der Gemeinschaftsgüter \\ Bonn \\ 2000/15
}

Law and Politics and Migration Research

Von

Roland Bank und Dirk Lehmkuhl 


\title{
Law and Politics and Migration Research
}

\author{
Roland Bank und Dirk Lehmkuhl
}

Oktober 2000

Max-Planck-Projektgruppe Recht der Gemeinschaftsgüter, Poppelsdorfer Alle 45, 53115 Bonn www.mpp-rdg.mpg.de 


\section{Law and Politics and Migration Research}

\section{1. $\quad$ Introduction ${ }^{1}$}

Given its concern with phenomena of a fundamentally transnational character, migration research may be regarded as a particularly fruitful field for interdisciplinary approaches which bring together lawyers and political scientists interested in processes of internationalization. In the European context, for instance, lawyers might ask for the input of political scientists because the relative immaturity of the common European legal stock on migration laws requires a certain knowledge of the historical, political and institutional background of the national provisions. Indeed, in recent years it has become increasingly fashionable for both lawyers and political scientists to emphasize the interdisciplinary character of their work, in particular in the sub-disciplines of comparative, international and European law on the one hand and comparative politics and international relations on the other.

Yet, notwithstanding that these two disciplines have rediscovered this, all too often the promise of interdisciplinarity is not kept. Rather, interdisciplinarity is confused either with a crude instrumentalization of other disciplines' knowledge while ignoring the underlying methodological assumptions or with an oversimplified dissolution of disciplinary distinctions. What is frequently missing is threefold: on a general level, a reflection of the potential gains and the potential risks or obstacles related to the collaboration of the two disciplines; on a more concrete level, a conscious awareness of complementary or compatible concepts and approaches; and finally, on the most concrete level, the identification of specific topics in which gains from common interests and cooperation can be realized.

In this paper we set out to assess the potential as well as possible shortcomings of studies by lawyers and political scientists which claim to be interdisciplinary. Starting from a lawyer's point of view, the argument is that migration research (not only) in the context is a promising topic for the collaboration of lawyers and political scientists. In their efforts to make proposals for European Community ${ }^{2}$ provisions lawyers might find it particular helpful to recruit on political scientists' capacity to analyze the embeddedness of norms in different societal and institutional constellations at the level of the Member States. The examples given in section 2 are followed by general considerations about the potential gains and risks of cooperation between the two disciplines (section 3).

\footnotetext{
* (Max-Planck-Institut für ausländisches öffentliches Recht und Völkerrecht, Heidelberg)

** (Max-Planck-Projektgruppe Recht der Gemeinschaftgüter, Bonn)
} 
It will be argued that an attempt to achieve the cross-fertilization of law and politics in general - and in the field of migration research in particular - does not require a mutual convergence of scholars from these different disciplines, i.e. that a scholar of one of these discipline becomes a scholar of the other counter discipline. Rather - and already demanding enough - disciplined interdisciplinarity is based on the mutual awareness of other (sub)disciplines' ontologies, epistemological assumptions and methodologies as indispensable preconditions for reaping the benefits of cooperation across disciplinary boundaries. At a very basic level, such an awareness facilitates not only the communication between lawyers and political scientists. Although not every problem of a lawyer may be translated into a problem of a political scientist, knowledge of the other discipline's thinking and arguing allows for cooperative work, for instance, by providing complementary insights on a specific topic.

\section{Migration Research as a Promising Terrain for Interdisciplinary Approaches}

In principle, a lawyer's educational background equips him or her with the methodological tools to analyze the context of laws on migration in the European Union and its Member States de lege lata, i.e., the rules existing on the national level and the legal framework set by international law and primary European law. Given a German legal education, for instance, the lawyer's traditional methodology for elucidating the meaning of a certain provision or a legal field includes various forms of interpretation: literal (including grammar), systematical (exploring the provision's position within the statute or other legal text in question), historical (using the history of the adoption of the text to be derived, for instance, from parliamentary debates) and teleological (reflecting the aim and purpose of the text). ${ }^{3}$ In order to analyze the legal situation with a view to potential inconsistencies, gaps, ambiguities and incompatibilities by employing norms incorporated in national constitutions or international treaties, the lawyer usually does not need the assistance of a political scientist. Yet, to answer questions such as why a specific set of rules is interpreted differently in different countries or why there is a gap between a written norm and its implementation it can be helpful to turn to political scientists, ${ }^{4}$ whose answers, in turn, might help the lawyer to make suggestions for new laws to be adopted (de lege ferenda).

In a similar vein, political scientists are well-equipped with elaborated methodological and analytical tools for describing and explaining the dynamics of a specific area or domain with respect to three dimensions: the formal aspect of institutions and rules (polity), the content and output of interactions of political actors (policy) and the procedural and conflictual dimension involving the process of policy-making in a certain institutional setting (politics). Yet, to fully understand the impact of a court decision, for instance, or the potential extent and limits for interpreting a certain provision, the political scientist has to rely on the lawyers' aforementioned methodology and their expertise (for instance Bengoextea et al. 2000).

In the present context, we claim that the policy on migration and asylum in the European Community constitutes a promising terrain for interdisciplinary endeavors. Firstly, although the European level has increasingly played a role in attempts to collectively deal with migration questions since the middle of the 1980s, and despite the fact that the Treaty of Amsterdam has turned the European Community into the main legislative forum in Europe for 
questions of migration and asylum, the common European stock on migration legislation is still relatively immature when compared to the longstanding tradition of national provisions. For the development of sustainable and pertinent common ground, it seems necessary to account for the diversity of historical, political and institutional embeddedness of national provisions - a task lawyers alone can hardly cope with. Secondly, it is in the very nature of migration that it is transnational in character. This implies that it is transboundary as migrants move from one territory to another and that it is translegal as it takes place within the patchwork of national provisions (Albert 1999, Friedman 1996). One major implication is that states can unilaterally only adapt to migration flows, but they can not guide them. To be able to purposefully influence or govern migration affairs requires coordinated action with other states. Multilateral coordination, however, significantly narrows the scope for idiosyncratic interpretations of legal provision. Rather, to arrive at recommendations that promise a successful harmonization of national migrations provisions and practices makes it necessary to understand the background of legal provisions and policies in other countries, which, in turn, approve political scientists counterpart of lawyers.

In order to arrive at valuable proposals for European solutions that can cope with the challenges arising from migratory flows, lawyers must not only analyze the legal texts governing the situation at a certain time, they also need a sound knowledge of the sociopolitical and socioeconomic background which led to the prevailing legal situation, both de jure and de facto. Moreover, to identify those factors representing new challenges, the lawyer needs empirical data and analytical information which political scientists are better equipped to provide by virtue of their professional education. Therefore, the task of adopting new legal texts for harmonizing the differing legal and empirical situations across the EU Member States provides a particularly interesting field for interdisciplinary research. The potential focal points of interdisciplinary cooperation shall be illustrated subsequently evoking the example of refugee law.

\subsection{The Definition of the Refugee as an Exemplary Model}

The central question of asylum law is, naturally enough, who is a refugee? What are the qualifying criteria for asylum status? National authorities grant asylum by applying the national law on asylum. Although, on the basis of the 1951 Geneva Convention, having a "refugee" status does not guarantee asylum, a great number of countries apply this definition when deciding on applications for asylum (Carlier 1997: 695). The interpretation by national authorities and courts differs greatly, however, and has given rise to comparative studies filling thick folios (for instance Carlier/Vanheule/Hullmann/Galiano 1997). A notorious example is the fact that most States view persecution by private actors as constituting a sufficient reason for granting refugee status, whereas Germany and France, in particular, refuse to do so; in this it ought to be kept in mind that the definition of "refugee" enshrined in the Geneva Convention does not specify exact criteria regarding who is to be legally considered the agent of persecution (Bank 1999: 13, Goodwin-Gill 1996: 70-74; UNHCR 1995: 28 ff.; UNHCR 1979: para. 65). While the better arguments indeed speak in favor of defining those persecuted by non-state agents as refugees, it may still be difficult to argue that the interpretation of the law by the German and French judges is so outrageous as to amount to an arbitrary bending of the law. This observation suggests that legal interpretation provides 
a lawyer with the possibility to react to certain problems divergently, without formally breaking the written law.

The lawyer may be content with having shown that the definition of a refugee under international law and under a comparative perspective does not require persecution by the State; in so doing he or she argues for an interpretation opposing that applied by the German and French courts. Yet, this is only part of the story, and another interesting question comes to mind: what are the reasons for the fact that the term "refugee" is interpreted by the courts of one State as including persons fearing persecution, regardless of whether this persecution is carried by state agents, while the courts in another State come to the opposite conclusion? This raises the issue of the borderline between legal interpretation and political decisions. We will come back to this phenomenon below when discussing the understanding of the politics behind a situation de lege lata.

The next fact to be considered in the present context is that a binding text more clearly specifying the requirements for an applicant for asylum will be adopted by the European institutions under the new EC-treaty framework inserted by the Treaty of Amsterdam. When trying to make informed recommendations for adopting this new law the level of policymaking has been reached. It is necessary to find out why certain States are interested in excluding those persecuted by non-state agents from the definition of a refugee, although, given their commitments under the European Convention on Human Rights, ${ }^{5}$ they are obliged not to send back such persons, even if the refugee definition under the 1951 Refugee Convention is interpreted restrictively. It is necessary to understand how normative criteria that can be derived from international treaties and how national constitutions can gain influence in the decision-making process inside European institutions. ${ }^{6}$ It is helpful to have a certain knowledge about the characteristics of the policy-making process in the multilevel European polity, that is a knowledge of how different national and European actors and institutions interact when making provisions. For instance, a question to be answered is why even though only two out of fifteen Member States fail to consider non-state agent persecution to be a sufficient criteria for the legal definition of a refugee, these two States may well manage push their restrictive interpretation through and may finally receive the support of all the other States. To answer these kind of question, a lawyer will inevitably fail to cope with an analysis of both the process of decision-making at the European level and its emdeddedness in domestic politics when recruiting only on his or her toolbox. Rather, help comes from political scientists who have in store a conceptional knowledge to delineate and interpret these processes and their implication for the European and domestic policies.

\subsection{The Example of Temporary Protection}

The discussion on temporary protection provides another example which may serve to elucidate the potential for interdisciplinary research in the field of migration and refugee law. "Temporary protection" aims to replace an approach which focuses on persecuted individuals and which leads to permanent status in the receiving country - as it is inherent in the present concept of international refugee law - with a generalized approach providing temporary refugee status in situations in which there are massive flows of refugees. Although not aiming to replace the asylum status in general, the Amsterdam Treaty has proposed that Europeanwide minimum standards for temporary protection ought to be elaborated and adopted within 
a five-year period. This indicates that temporary protection is likely to complement the traditional asylum approach more and more often within a few years.

When trying to cope with a situation in which the individual approach in refugee protection has entered its twilight, the educational capacities of lawyers are traditionally limited and might require additional information provided by political scientists' analysis. The lawyer will analyze the application and interpretation of the refugee definition and determine the differences between countries. Moreover, he or she will be able to observe that a certain set of laws (in particular, the extension of visa-requirements) makes it more difficult for potential asylum seekers to enter the country of destination in order to claim asylum or even to submit the asylum application in the country of the applicant's choice (for instance, due to the safe-third-country concept or the distribution of asylum claims among EU Member States according to the Dublin Convention). And, the lawyer will ask whether this state of affairs fittingly reflects the idea of protection for refugees as enshrined in international instruments.

In addition, a lawyer will be able to understand the mismatch between the current concept of refugee protection and actual challenges that are linked to the change in the composition of refugee flows. A number of reasons such as decolonization, secession struggles in Africa and Asia and nor increasingly civil wars and generalized violence. led to a multiplication of the courses of refugee flows from the 1960s onwards. From a legal point of view, an ever smaller proportion of persons seeking asylum in the West are seen to fulfill the criteria of the refugee definition in the Geneva Convention. Political scientists' knowledge might provide additional insights in how the individual approach in refugee protection has largely been circumvented: barriers have been erected or underpinned which prevent people in need of protection from reaching the host country and consequently from being able to submit their applications for asylum (Hathaway 1997). Or, freedom from persecution is assumed for certain countries by way of a generalized judgement such as safe third country rules (Lavenex 1999a).

Also, with a view to arriving at suggestions for a future concept in the European context in which asylum and temporary protection could be accorded complementary roles - a thorough analysis of the prevailing legal framework as well as the institutional context and the underpinning social phenomena is required. In particular, the basic tension between the human rights of persons temporarily protected and the interest of host states to avoid factors that foster a situation in which the refugees do not return home must be fully explored before valuable suggestions for a future policy in this area can be made. While the human rights requirements might productively be analyzed by a lawyer, the impact that granting certain rights has on the potential for repatriation after a certain time requires the type of careful analysis for which political and social scientists are better equipped. This may even lead to the conclusion that both perspectives - the guarantee of living in human dignity and the aim to prevent integration from leading to a "non-return" effect - are irreconcilable. Moreover, it is likely that the concept of temporary protection will only work if it is embedded in sound measures providing for repatriation aid and the sharing of responsibilities and costs. Again, these aspects are not within the lawyer's sphere but require input from political scientists. ${ }^{7}$ 


\subsection{Interdisciplinary Cooperation as a Contribution to a Fuller Understanding of the Law as It Stands}

The use of political science methodology when reflecting on how to make certain normative aims inherent in international treaties or national constitutions more effective only represents one potentially fruitful aspect of interdisciplinary approaches to migration research. In the course of a lawyer's analysis further potentially profitable aspects are also to be found.

The relationship between the approach of a lawyer and a political scientist may be characterized as such: while the lawyer looks at the letter and system of the law and therefore at the visible outcome, the political scientist looks at the processes which led there instead, the politics lying behind it, and how things work in practice, reflecting a large variety of influential factors (ideally including the legal ones). This, however, is a simplification since a lawyer may also need aspects from the political scientist's research basis and vice versa. For instance, if it proves necessary to historically interpret a norm, a lawyer may have to take recourse to a political scientist's analysis of the process of drafting a law - including the discussions in the political process of arriving at the final compromise. Also, interpreting a legal text in accordance with its aim and purpose may prove difficult without going back to the political process that led to the adoption of the provision or the text in question.

The differing court interpretations of the same term indicate that sometimes the borderline between political science and law is even more blurred since the application of law, by both the national authorities and the courts, is not free from politicization. This is plainly clear, for example, when the term "refugee" from the 1951 Geneva Convention is interpreted in a different manner in different European States, as in the above-mentioned case. From this example we learn that the simplistic assumption of the process of norm creation falling into the realm of political scientists and the interpretation of the existing law being the exclusive realm of lawyers is clearly flawed for at least two reasons. On the one hand, the application of law does not take place in a sterile environment but law is applied by human beings who are susceptible to external influences and their own convictions, which both will find their way into the judges' decisions. On the other hand, the application of laws implies a significant potential for innovation (Okruch 1999), and processes of norm-development or norm-creation in the course of the application of existing provisions are a well-established and well-accepted rule rather than an exception (Christensen 1987, 82). In the European context, the enormous importance of judgements of the European Court of Justice for the entire integration process has frequently been emphasized (Burley and Mattli 1993; Weiler 1993, 1994). With respect to fundamental rights, it is more courts than parliaments that decide on the extension of individual rights and on the limits of public intervention into these.

Concerning the different interpretations of the refugee definition, the deviance of French and German courts from the generally-accepted interpretation of the term in regard to the issue of non-state persecution could possibly be explained in reference to the national situations underpinning the decisions. That is, a strong tendency in Germany to stem the generally very high number of asylum-seekers by the use of restrictive policies may have found its way to the courts' interpretation. And in considering France it cannot be overlooked that it is the main country of destination for asylum seekers from Algeria, which for its part, is one of the countries that produces the largest number of individuals fleeing persecution by non-state actors, i.e., the fundamentalist terrorists. 
As has been emphasized above, while good arguments speak against the interpretation accepted by the German and French courts, the arguments are not strong enough to lead to the conclusion that the French and German law courts are engaged in arbitrarily bending of the law. Rather, different interpretations are possible within the interpretive boundaries. This puts courts in a position of reacting to social phenomena to a certain extent, without having to wait for a formal amendment of the law. Confronted with these findings, the lawyer will mainly be interested in the outcome of the process, i.e., in analyzing the pros and cons of the line of argumentation adopted by the courts in reacting to a new phenomenon. In contrast, the political scientist will be more concerned with showing which factors may have influenced this outcome.

Without being underpinned by careful research, eventual explanations may seem plausible, but they remain mere speculation. To find out more about the true reasons would require an interdisciplinary endeavor with a lawyer analyzing the exact argumentation of the courts in the relevant cases and a political scientist trying to shed light on the way political baselines find their way into courts' decisions.

While a lawyer may manage to cope with the challenges of legal interpretation without having the slightest idea of political science analysis, there may be situations in which discovering the politics underpinning a particularly complicated set of norms may provide elucidating insights. Understanding the politics behind the situation de lege lata is not only valuable as such, it may also contribute to reflections on the need for reform that transcend mere legalistic issues, such as conformity with superior norms or achieving consistency within a given legal system.

An example of this is provided by an analysis of the reception of asylum seekers from the point-of-view of comparative law, which was carried out for an interdisciplinary conference on "Migration and the Welfare State" (Bank 2000). A review of the legal rules governing the liberties and social conditions for asylum seekers in four different European States with regard to detention and restrictions on free movement and the choice of residence, on the one hand, and working opportunities, housing, social aid and education, on the other, brought to light a great variety of applied models. Of course, the differences in legal provisions and entitlements granted to asylum seekers became all the more vivid by contrasting them with each other. However, in the near total absence of international norms that could have provided normative guidance regarding which of the rules were open to criticism, the large number of details seemed more confusing than elucidating. From a purely legalistic point-of-view there seemed to have been no system behind the variety of models applied in the different States, only the tendency to restrict asylum seekers' rights and entitlements.

Only after reflecting on the policies - in an interdisciplinary discussion involving lawyers, political scientists and sociologists - was it possible to reveal, not only the obvious aims of deterring potential asylum seekers and limiting the amount of money spent on those who continue to arrive, but also another principle underpinning restrictive measures: the aim to limit integration and access to economic, social and cultural benefits in order to avoid any developments that could hinder the expulsion of the asylum seeker if his or her claim were rejected.

These reflections allowed us to draw the conclusion that the treatment accorded to asylum seekers has a purpose that runs in contrast to the usual intention of welfare benefits: the latter serve to preserve or to foster (re)integration, while the treatment of asylum seekers during the 
reception phase serves to impede integration. By excluding asylum seekers from taking part in the daily life of the host society as far as possible, States try to ensure that the law enforcement intended for rejected asylum seekers is not impaired by irreversible structures of social ties. Therefore, it was possible to show that the treatment of asylum seekers, from the time of their arrival to the final decision on their claim, is dominated by the tension between the two contrary goals of reception policies. One goal is to ensure the exclusion of asylum seekers from European societies. The other goal to ensure that asylum seekers survive with a minimum of human dignity, as is demanded by the values of modern welfare states which are committed to humanity. Having understood this, it was possible to show that the main problem to be addressed is not restriction as such but the question concerning how long restriction may be applied without violating human dignity.

\section{A Broader Conceptual Framework for Interdisciplinary (Migration) Research}

The previous section has illustrated that the (inter)disciplinary cooperation between lawyers and political scientists not only has normative claims, it is also a fruitful enterprise. Indeed, since scholars in both disciplines are preoccupied with the same empirical phenomena, overcoming academic insularity and building bridges is a repeated demand (e.g. Abbott 1989; Beck et al. 1996; Byers 2000; Chin/Choi 1998; Slaughter Burley 1993; Slaughter 1995; Slaughter et al. 1998; Young 1992; International Organization 2000 [vol. 53, no. 3]). But is it right, for example, for international law and international politics to cohabit the same conceptual space (Slaughter 1995, 503)? Or should there be a division of territories in which different disciplines examine the same phenomenon from different foci, on the one hand, with overlapping segments of disciplines spurring a recombination of knowledge in specialized fields, on the other (Dogan 1998, 123)?

While putting some effort into achieving cross-disciplinary fertilization seems promising, to do justice to the demanding task of interdisciplinary cooperation between law and politics a number of obstacles related to conceptual, methodological and organizational preconditions are faced. Some of these important preconditions will be delineated in the following by, firstly, considering some aspects that suggest the pooling or accumulation of knowledge and experience from political science and law, and, secondly, pointing out hindrances to achieving cooperation across disciplinary boundaries. In a third step we shall elaborate on our idea of disciplined interdisciplinarity.

\subsection{Interdisciplinary Utopia}

A couple of years ago a prominent professor of international law felt so inspired by the natural affinity between law and politics that he forecasted the emergence of a new joint discipline called the "study of international cooperation" (Abbott 1992). For him, law and politics in the disciplines of international law and international relations were "so neatly complementary that they can enrich each other tremendously across a wide range of intellectual activities" (Abbott 1992, 168). At the end of the day, according to his forecast, the 
new joint discipline would bear the potential of transcending its constituents much the same way as the law and economics movement had (ibid.).

Abbott elaborated the potential of the mutually-supportive activities along five dimensions: descriptive, doctrinal, explanatory, normative and instrumental. First, the importance of description in both disciplines is almost self-evident. Nevertheless, there are significant differences in how it is practiced. Political scientists frequently complain that the legal approach to international affairs relies on textual exegesis to the exclusion of political, economic and other realities. In this regard, political science, with its strong interests in generalization, has shown that the value of description increases when it is theoretically informed. Neo-institutional and frame-analytical approaches, for example, have been best suited to explain both the manner and direction in which migration and asylum policy has developed in Europe since the beginning of the 1980s. Trans-governmental working groups have successfully circumvented the national scrutiny of courts and parliaments and, in addition, have managed to frame questions of asylum policies in security rather than in humanitarian terms (Guiraudon 2000; Lavenex 1999b).

Second, the analysis of doctrine, i.e., the analysis of norms and their application to the factual situation (Abbott 1992, 168) and the principles underpinning it, is an essential function of law as a professional discipline, while it is largely missing in political science - although the cognitive turn in political science indicates an increasing attention given to the ideas underlying certain policies. Through legal reasoning - understood as the way in which lawyers frame legal arguments and in which other lawyers respond to these arguments doctrinal analysis may provide insight into central questions of international relations and help to understand whether and how international obligations constrain State behavior. For instance, as subjects of international law one might ask whether and under which circumstances legal doctrine can become so influential so as to constitute a factor independent from the States.

Third, explanation, of course, is an important dimension in both disciplines. There are, however, significant differences assigned to the role of explanation. While for a political scientists explanation is the central category, for a lawyer explanation is only a first step on his or her way to come to a normative decision. What is more, both disciplines view assign different importance to the explanatory value the respective has to offer and an awareness of mutual prejudices may help to reveal complementary aspects.

On the one hand, from a political-science perspective law is often seen as being theoretically uninteresting; it tends to confuse cause with appearance as it focuses predominantly on 'justificatory behavior'. That is, the law is seen as "conflating the sources of international law with actual state behavior" (Joyner 1987, 387f). On the other hand, lawyers are either amused or annoyed by political scientists' efforts to properly label dependent and independent variables (Beck 1996, 18). Because political scientists long failed to view international law as either a dependent or independent variable of importance for the conduct of states, lawyers are quick to accuse internationally-oriented political scientists of failing to appraise the role of law carefully and all too often of failing to consider where and how international law fits into the calculus of national policy-makers or international diplomacy (Joyner 1987, 388). In recent years, however, the collaboration between lawyers and political scientists has become more fruitful. With respect to bargaining and foreign policy decision-making, for example, lawyers' historical interpretations have benefited from 
political scientists' studies of the bargaining process, and have at the same time contributed to political scientists' awareness of the legal arena (Gould 1987, 384). Law is no longer regarded through an instrumentalist optic (Keohane 1997) but as a variable in its own right (Kratochwil 2000; Slaughter et al. 1998; Young 1994).

On a more abstract level, we can reformulate the potential for mutual benefits of explanatory methods deriving from cooperative work between law and politics in the following way. In epistemological terms, traditionally, as today, law relies to a certain extent on its own history (Engel). ${ }^{8}$ The reliance on its own history is partly derived from the need for coherence that urges the judge to accommodate his or her decision - or interpretation of a certain legal text - with both precedents and an historical interpretation of the given legal situation. Put more poignantly, "in no other branch of learning (except perhaps religion) does perceived wisdom enjoy a preferred position over newly revealed insights" (Knetsch 1998, 19). Yet, this reliance on its own historical knowledge has an significant drawback. The fact that law is principally a discipline in which theories about social reality, about societal interest and conflicts are missing, gets law into trouble when it is dealing with contemporary problems. Law is incomplete and has to borrow from other disciplines' concepts and theories if it wants to describe, analyze and regulate such problems (Joerges 1974, 557; Slaughter et al. 1998, 371). This shortcoming can only be remedied to a certain extent through a dynamic interpretation of legal norms; and dynamic interpretation is all the more difficult the more detailed existing legal rules on a certain questions are.

Fourth, it is normally thought that the conduct of normative analysis in both a critical and prescriptive assessment of norms, practices and institutions plays an important function in law and politics. The objective of normative analysis is to critically scrutinize existing arrangements and to prescribe preferable alternatives. Yet, as will be discussed below in more detail, the two disciplines weigh this category significantly differently.

Fifth, the quality of the instrumental work achieved through the disciplinary cooperation between law and politics is viewed as particularly noteworthy. In this respect, the descriptive and explanatory help of political scientists is not only supposed to enrich lawyers' studies of the implementation of treaties and other international agreements. On the one hand, the application of law is at the heart of legal studies; but lawyers seldom have scientific knowledge in assessing the pertinence and efficacy of the laws in a changing society. On the other hand, the social sciences have a deeper understanding of the political, economic and social changes in a society, and developing and testing of hypotheses is at the heart of their scientific interest: yet, because of the lack of familiarity with legal technicalities, social scientists are not in the position to propose concrete legal and policy changes (Chin/Choi $1998,1)$. Thus the disciplines are complementary in many respects, and through cooperation between them it should be possible to improve the potential for analyzing substantive problems, developing of new concepts for particular institutions and framing better legal solutions (Beck 1996).

In sum, these considerations tend to support the call for interdisciplinary cooperation in the effort to scientifically treat the unavoidable blind spots deriving from disciplinary differentiation and specialization (Bommes and Maas in this volume). What is still missing, however, is the proof that merging the collaborative enterprise into some kind of brave-newworld of interdisciplinarity is really the ultimate means to achieving this goal. Indeed, in what follows we will discuss some serious obstacles which hamper such enthusiasm, and which 
thus significantly lower expectations about the possible achievements to be attained by the cooperation of law and politics.

\subsection{Obstacles for interdisciplinary cooperation}

At first glance, one might argue that while frequently dealing with the same subjects in the real world, both fields are trapped in the routine approaches of their own discipline. As such, lawyers and political scientists become victims of their own rhetoric, and their prejudices become self-fulfilling prophecies. The gap between the disciplines, however, is a deeper one. A closer look at the limits of disciplinary cooperation between law and politics reveals some important structural impediments. In the following, we elaborate only on two of these obstacles: the differentiation in scientific development and the difference between analysis and advocacy. ${ }^{9}$

\section{Differentiation and Specialization in Science}

Even a very brief glance at the histories of the disciplines at stake confirms that neither law nor political science are exceptions to the general rule of differentiation and specialization characterizing so much scientific development. Their common background can be seen in the discipline of Staatswissenschaft encompassing in a broader sense legal, political and economic affairs. They have, however, developed in different directions and the disciplinary emancipation from this more encompassing concept occurred not only between the various disciplines, but also within them. It occurs along cultural, historical, geographical, ontological, methodological and epistemological lines. Schools and sects divide disciplines (Almond 1990), making the domains and interests of social scientists and lawyers thoroughly heterogeneous, thus contributing to an 'epistemological pluralism' (Young 1992, 174). Given the dramatic increase of expertise that goes alongside differentiation and specialization within individual disciplines, it is stated to be "no longer possible for anyone to have thorough knowledge of more than one discipline" (Dogan 1998, 98). This assumption renders the ability of individual scholars to be familiar with and combine entire disciplines illusionary and, rather, endangers the individual struggle for interdisciplinarity to "carry a hint of superficiality and dilettantism" (ibid., 99; Chmielewicz 1994, 26).

These considerations suggest that in a strict sense the word interdisciplinarity appears inadequate. To be more precise, one would have to speak of efforts to combine fragments of different disciplines or of a recombination of specialized knowledge. While the consequences of this recombination for the concept of a cooperation between lawyers and political scientists are discussed in more detail below (3.3.), we can restrict our reflections at this point to structural points limiting interdisciplinary work. In this regard, two aspects need to be distinguished. On the one hand, on has to admit that there are examples in which a legal scholar having done some basic studies or having acquired an LL.M. degree in political science may well combine methodologies and theoretical models in one research project with highly inspiring and interesting outcomes (for instance Noll 1997; Marauhn 1998). But such interdisciplinary single-handed endeavors will remain the exception rather than the rule. In addition, as science is always a concert of many and progress rests at least as much on 
cooperation as on the inspiration of the individual (Dahrendorf 1968, 14), individual efforts do not further help to systematize interdisciplinary research fora.

Cooperation across disciplines, on the other hand, is not only hampered by individual knowledge capacities, but also by professional pillarization. In particular, cooperation is troubled by entrenched practices in the two disciplines: the professions are organized in neatly separated professional associations, and discourse takes place at different conferences; scholars tend to publish (and read?) almost exclusively in the journals of their own disciplines; narrow vocational agendas put more emphasis on uni-disciplinary, technical training and provide only a few incentives for gaining knowledge in other disciplines; and, finally, a different disciplinary socialization implies that different languages are internalized, and the same terms are often assigned different connotations, which frequently impedes interdisciplinary communication at a very basic level (Beck 1996, 19f; Drewry 1998, 194; Kirchner 1991; Young 1992, 175).

\section{When science ceases and advocacy begins}

There are even more factors that hamper the cooperative effort between political science and law. Frequently, political scientists have difficulties in following the lawyers' efforts to accurately characterize the substance of the law instead of its causal relationship(s) to specific behavior. Moreover, given the importance that political science scholars traditionally assign to the realities of power in international relations, international law's aspiration for universal justice and moral attainment have a hopeless utopian character in these scholars' eyes - while lawyers are critical of wholly reducing real-world politics to power considerations or numerical calculations (Joyner 1987, 389). In addition, with its concern for theorizing and generalization, political science is seen as being preoccupied with scientism; and this is viewed as hampering pragmatic and inductive research.

But nota bene: "law and politics are not one continuum in the realm of praxis, but radically different domains that have to be kept differently" (Kratochwil 2000, 39). In this regard, the examples clearly indicate the different ends toward which a political and a legal academic education are directed: analysis and advocacy, respectively (Beck 1996, 18). Crudely spoken, political scientists and lawyers often ask different questions and expect different answers. In an (admittedly) simplistic way, these differences can be presented as follows.

Political scientists have a prevailing interest in positive analysis ${ }^{10}$ and they "pursue the grail of explanation and prediction" (Young 1992, 174). By asking, for instance, how institutional constraints empower or restrict consequential actors differently, how collective action problems are solved and what institutional solutions have been created to provide common goods, political scientists are concerned with descriptive and causal interference on the one hand, i.e., with impediments to action and goods, (King et al. 1994, 7f) and with generalizations about polities, politics and policies on the other. To satisfy their interests in interference and generalization, social scientists take different avenues, weighing the relative merits of meta-theories or middle-range theories (Merton 1996; Benz and Seibel 1997). To summarize the difference, political scientists try to explain a certain action or observation and try to arrive at general conclusions on regularities of political behavior. In contrast, lawyers start with a given norm under which they try to subsume a certain action in order to evaluate 
whether this action fulfills the criteria characterizing this norm. Their interest is less in generalization but either in sanctioning non-norm conform behavior or in making recommendations for law amendments.

The statement that the interest of (mainstream) lawyers differs significantly from that of (mainstream) political scientists can be substantiated in relationship to two aspects, i.e. the purpose of legal reasoning and the gap between law-in-theory and law-in-practice as the central issue for studies about law. With respect to the former, it has already been mentioned that legal reasoning, as the characteristic discourse of the legal community, is very particular. While largely lacking interest in generalizations, this discourse serves to fulfil the twofold function assigned to law: resolving disputes and actual social conflicts, on the one hand, and accommodating the need for maintaining historical continuity, doctrinal consistency and coherence with societal change and evolution, on the other. Lawyers are concerned with formulating principles or doctrines and with applying these principles methodologically to specific cases or factual patterns. The relation between principles and factual patterns is dialectical.

"One wants to use principles to understand cases and fact patterns. How can you understand a case or a fact pattern without making decisions and deploying some principles? And one wants to use cases to derive principles. One wants a constant dialectic between the principles and the case. It is not a matter of constructing more or less powerful generalizations; it is a matter of developing a dialectical process that allows both for the refinement of principles and for the solving of cases, because cases must be solved - the dialectic is not just an intellectual exercise" (Young 1992, 175; emphasis added by the authors).

In short, there is a significant difference between political scientists' strivings for explanation, prediction and generalization on the one hand and lawyers' concerns with formulating principles and applying these principles to decide concrete cases on the other. To arrive at generalization for an unlimited number of potential cases, political scientists try to reduce the number of explanatory variables as much as possible. This interest in abstract conclusions is in stark contrast with lawyers' methodology of interpretation that aims to contextualize the interpretation of a specific norm and the subsequent decision or judgement to the highest possible degree.

There is a second factor of major concern to legal scholars that frustrates disciplinary cooperation: namely, the interest in the gap between law-in-theory and law-in-practice. ${ }^{11}$ In this respect, the issue of compliance with international norms can not only be taken as an example of successful cooperation between lawyers and political scientists, ${ }^{12}$ but also may help to delineate the difference between positive and normative analysis. International lawyers have traditionally emphasized the elaboration of rules that are notionally binding upon states. So doing, they have built institutions to help shape and interpret those rules (Toope 2000, 92). Frequently, however, they have been frustrated by the lack of state compliance with international provisions. In this respect, regime theory of political science with its analysis of institutional factors influencing the effectiveness of different regimes has contributed insights in the formation and influence of both conventional and customary law. In this regard, we agree with Abbott's fifth dimension, according to which the combined 
knowledge of lawyers and political scientists might be used instrumentally and contribute to a reformulation of a specific legal framework.

At the same time, however, in the instrumental dimension we are confronted with a problem that is probably as old as science itself: the application of scientific results to practical problems (Dahrendorf 1968). In this respect, the compatibility between law and politics tends to cease when positive analysis ends and normative analysis begins. By transgressing the positive-normative divide, science frequently ceases and advocacy begins. In the following we want to illustrate these considerations by briefly pointing out the different importance political science and law assign to positive and normative analysis on the one hand and advocacy on the other.

To start with, in the context of policy research the objective of political science and political sociology is to contribute to the understanding of politics and the conditions under which it is able to produce effective and legitimate solutions to policy problems. While this assessment indicates that positive and normative investigations are closely related, the claim remains that the one must not be confused with the other (Scharpf 1997, 13). Indeed, in political science there is a relatively strict distinction between analysis, normative claims and the use of achieved knowledge for the purpose advice. When normative analysis becomes part of the work of the political scientists, the criteria for its normativity relate to central categories of the discipline such as transparency of decision-making for democratic reasons or the relative importance of power in decision-making processes. To give an example, from a political science perspective, the actual formulation of asylum legislation in the Central and Eastern European countries would need to be interpreted against the background of enlargement negotiations with the European Union and the power relations inherent in these processes. In this perspective, the candidate countries have been incorporated into a restrictive system of migration control including the negative distribution of asylum seekers in exchange for the perspective of becoming EU Member states. Equally, the fact that in the European context asylum and refugee questions were framed in terms of internal security affairs at the expense of human rights principles of international refugee protection in the first place, could be explained with reference to domestic interests and the dominance of civil servants related to the ministries of the interior in the intergovernmental decision-making process at the European level (Lavenex 1999a, b).

This examples indicates that in political science a positive analysis of political processes and its measurement against normative criteria is possible. What we want to emphasize here, however, is that in political science the distinction between analysis and the instrumentalization of its reflexive apparatus and its methodology for purposes of advocacy is sharper than it is in law. To elaborate the argument that law is inherently more prone to normative judgements and that this normativity is not only more consequential for the behavior of individuals and political institutions than that of political science but also easier runs the risk to incorporate value judgements, we like to distinguish two major legal professions, that of a judge and a legal scholar.

As already mentioned, a judge is always confronted with a twofold task. On the one hand he or she must subsume a specific action under a respective norm in order to arrive at a judgement that guarantees individual justice. On the other hand, the judge has to account that the individual case is in coherence with precedents and, in addition, he or she has to constantly measure reality with normative principles. As already mentioned, in case of 
disparity between legal reality and the ideal or principle judges frequently close this gap either by interpreting the norm according to societal developments or by introducing new elements into the interpretation of a norm. So doing, however, the judge inadvertently runs the risk of implanting personal ideals as the society's ideals (Esser 1970). This is the more critical when 'decisions are thought from the result', thus taking the character of politicized decisions in the guise of legal judgements (Müller 1994, 11).

In particular in international law the boundary between those applying law and those doing legal research is frequently blurred. Courts look at normative scholary as a source of law and international law academics tend to see themselves as part of the 'invisible college' devoted to world justice (Goldsmith 2000, 981f). In addition, lawyers are trained to use normative arguments and to convince political decision-makers to move law in a direction deemed favorable. One has to bear in mind, however, that similar to provisions within the domestic constitutions international treaties are open to diverse interpretations, so that the process of interpretation can become one of advocacy. As such, advocacy scholarship is not inherently bad or undesirable. But when scholarship is characterized by policy prescriptions that reflect author preferences (Dunhoff and Trachtman 1999, 24), the worry is simply that it jettisons methodological rigor and tends to selectively and tendentiously support normative conclusions (Goldsmith 2000, 982).

In brief, a political science problem is first of all a problem of descriptive and causal interference and of matching general explanation with reality. In contrast, a legal problem is on the one hand a problem of contextualization and not of generalization on the one hand, and of comparing legal reality with a legal ideal on the other. When it comes to making recommendations to resolve disparities between the two, science very often ceases and advocacy begins. Then a legal problem becomes a value problem and, as such, beyond the reach of political science. Thus, the core problem of legal policy-making becomes a problem of value (Black 1982, 1087). In principle, value considerations are irrelevant to any scientific theory of the empirical world. Political science, for instance, rejects value loaded considerations as "value judgements are no doubt relevant as foreign policy considerations, [yet] they are obviously highly subjective quantities; consequently, they do not always lend themselves to scientific or rational analysis" (Joyner 1987, 388). To be sure, value-free science is hardly possible. But the fact that scientific statements are influenced by values does not make them value statements (Black 1982, 1095). Hence, put more generally, there is a clear distinction between the indirect intelligence function a positive scientific analysis takes for the policy process and an implicit or explicit normative analysis fuelling advocatory policy recommendations.

\subsection{Disciplined Interdisciplinarity}

So far we have learned that the cooperation between law and political science is a worthwhile undertaking. Potential benefits would be lost if the formal borders between the two disciplines did not allow for transgressions in the one or the other direction. Indeed, both disciplines can benefit from exploring the enormous hinterland provided by the other. Yet, it has been demonstrated that cross-disciplinary cooperation will not be handed to anybody on a silver plate but requires serious scholarly study. In addition, there are significant obstacles that 
impede the realization of an interdisciplinary utopia in which disciplinary distinctions dissolve.

It is not by accident that we have frequently coupled international law/international relations when referring either to potential gains or hindrances. References to subdisciplines have been informed by the fact that the historical evolution of science in general can be read as a twofold process: fragmentation of formal disciplines and recombination of specialties resulting from the fragmentation. Thus, specialization is regarded as a precondition for progress in science (Dogan 1998, 97). On the one hand, specialization takes place within a formal discipline. It becomes institutionalized and leads to fragmentation. On the other hand, specialization occurs at the intersection of monodisciplinary subfields; that is, a recombination of the fragmented specialities could be observed (so-called hybrids). As sociometric studies have shown, it is significantly more important for specialized scholars to interact with colleagues of other disciplines than it is for them to interact with those of their own discipline (Dogan and Pahre 1989).

What is important in our case is threefold: first, that at least up to some point, disciplinary boundaries are of utility in advancing knowledge, because "[e]ach discipline throws light on a set of variables precisely because other factors are assumed to be external" (Sartori 1969, 66); second, innovations in the social sciences are most often the offspring of cooperation between specialized subfields. An important example is the field of political economy, which, without doubt, integrates many cutting-edge scholars from political science and economics, both at the national and international level; finally, these hybrids do not stand midway between the two sovereign disciplines. Rather, the respective disciplinary background maintains a visible profile (Dogan 1998, 100).

These considerations constitute the basic assumptions that ought to be borne in mind when considering our call for disciplined interdisciplinarity. Cooperation across sub-disciplinary boundaries is desirable; it is a worthwhile undertaking since the many reciprocal influences and opportunities make overcoming mutual ignorance possible. As such, we would counter those who propose that the specialization and division of labor yields enormous benefits in the production of all goods and services, and that knowledge and its application is no exception (Knetsch 1998, 11). Rather, from our point-of-view, cooperation across the boundaries of law and the political science makes two things possible: first, it makes it possible to achieve a more encompassing understanding of societal change in turbulent environments; and second, it makes it possible to arrive at recommendations based on sound empirical description and theoretical interpretation. There are thus good reasons for a summon to disciplined interdisciplinarity. This summon, however, should not be confused with a summon to blend the approaches of lawyers and political scientists. Rather, the summon to engage in disciplined interdisciplinarity is the summon to preserve differences between scientific disciplines. This rather modest approach is due to a number of profoundly different commitments of the two disciplines of which we have discussed only two above. Thus, we are convinced that only both the awareness of one's own educational pedigree and a sound knowledge of the other discipline's epistemological assumptions and methodologies allow us to reap the benefits of cooperation between lawyers and political scientists. 
As aptly shown by our brief empirical examples, it is fruitful to approach the field of migration research as a cooperative effort between legal and political science. In the first case examined, the lawyer's lenses alone failed to take into view the entire context relevant for a refugee definition in European Community Law that could sufficiently serve us in the future; it thereby limited the potential for making valuable and adequate recommendations for norms to be adopted. Moreover, sticking solely to legal methodology, the lawyer could not explain the background informing the diverging interpretations of the same international norm by French and German courts. Similarly, the second case demonstrated that the new concept of temporary protection which is to be adopted by the European Community not only requires an analysis of human-rights norms that limit the possibilities of choice; it also requires wellfounded information of the sociopolitical impact of eventual action to be considered with these norms. Finally, in the third case, only after interdisciplinary discussion was it possible to identify the tension between the two contrary goals that govern the reception policies in some Member states of the European Union. In all these cases, two things become apparent. The first general observation is that law has to be contextualized, i.e. that law is best understood within the context of history, and of political and economic forces. The second observation refers to the finding that law is almost always refracted through a political process and that the political dimension needs to be studied carefully (Falk 1993, 399).

We take this positive evaluation of the cooperation between legal and political science to re-emphasize the importance of efforts to cross disciplinary boundaries in research. Yet, such cooperative work can neither be reduced to instrumentalizing other disciplines' knowledge or concepts nor with blurring disciplinary boundaries. Rather, the knowledge of one's own disciplinary pedigree has to be combined with a well-informed understanding of the counter disciplines' epistemology and methods. From our point-of-view three aspects are at the heart of the view of disciplined interdisciplinarity as exercized at the inroads of law and political science.

First (conceptually), scholars of each discipline should be aware of conceptualizations and methods of the other respective discipline to enable them to appreciate, evaluate and utilize what the other discipline has to offer. Potential candidates for such a collaboration are, for instance, scholars of international law and international relations, comparative lawyers and comparative governmentalists, private lawyers and political scientists with a particular focus on the role of private actors, legal and political science scholars studying the process of European integration, etc.

Second (methodologically), in cooperating with specialists from other subdisciplines, positive and normative analysis should be separated; and, even more important, science should not be confused with advocacy. Otherwise the risk is that methodological rigor is sacrificed on the altar of - value loaded, normative - policy recommendation or suggestions de lege feferenda.

Third (organizationally), vocational changes need to be brought about by organizational changes, including changes in finance. Vocational changes such as reforms in curricula may prepare the ground for a scholarly awareness of the benefits of cooperating with neighboring subfields. Because of the outpouring of documentary and scholarly material today, individual 
efforts to bridge the gap between the two fields merely constitute the necessary starting points for the cooperation across disciplines. But it is imperative that these efforts narrow the focus of their study. In order to spur on interdisciplinary cooperation it is thus necessary to improve vocations, either by supporting institutionalized cooperation within faculties or proper institutes, or by finding funding opportunities that allow communication costs to be overcome in scholarly cooperation. 


\section{References}

Abbott, Ken. 1992. Elements of a Joint Discipline. Proceedings of the 86st Annual Meeting of the American Society of International Law (International Law and International Relations Theory: Building Bridges). Washington, D.C.: American Society of International Law, 167172.

Albert, Mathias. 1999. Entgrenzung und Globalisierung ds Rechts. In: Globalisierung des Rechts, edited by R. Voigt. Baden-Baden: Nomos. 115-139.

Almond, Gabriel A. 1990. A Discipline Divided. Schools and Sects in Political Science. Newbury Park: Sage.

Bank, Roland. 1999. The Emergent EU Policy on Asylum and Refugees - The New Framework Set by the Treaty of Amsterdam: Landmark or Standstill?, Nordic Journal of International Law 68, 1-29.

Bank, Roland. 2000. Europeanising the Reception of Asylum Seekers: The Opposite of Welfare State Politics, in: M. Bommes and A. Geddes (eds.), Migration and the Welfare State, London: Routlegde (forthcoming 2000).

Beck, Robert J. 1996. International Law and International Relations: The Prospects for Interdisciplinary Collaboration. In: International Rules. Approaches from Interantional Law and International Relations, edited by R. J. Beck, A. C. Arend and R. D. V. Lugt. New York/Oxford: Oxford University Press. 3-33.

Bengoextea, J. R.; MacCormickN., Moral Soriano, L. "Interpretation, Integrity and Integration at the European Court of Justice", J. Weiler (ed.) Oxford UP 2000.

Benz, Arthur, and Wolfgang Seibel, eds. 1997. Theorieentwicklung in der Poltikwissenschaft. Eine Zwischenbilanz. Nomos: Baden-Baden.

Black, Donald J. 1982. The Boundaries of Legal Socialogy. The Yale Law Journal 81: 1086-1100.

Burley, Anne-Marie, and Walter Mattli. 1993. Europe before the Court: A Political Theory of Legal Integration. International Organization 47: 41-76.

Byers, Michael, ed. 2000. The Role of Law in International Politics. Essays in International Relations and International Law. Oxford: Oxford University Press.

Carlier, Jean-Yves, Dirk Vanheule, et al. (eds.) 1997, Who is a Refugee? A Comparative Case Law Study, The Hague et al.: Kluwer.

Carlier, Jean-Yves. 1997. General Report, in: Jean-Yves Carlier, Dirk Vanheule et al. (eds.) Who is a Refugee? A Comparative Case Law Study, The Hague et al.: Kluwer.

Chin, Anthony, and Alfred Choi. 1998. A Tender for Symbiotic Partnership between Law and Social Science. In: Law, Social Sciences and Public Policy, edited by A. Chin and A. Choi. Singapore: Singapore University Press. 1-10.

Chmielewicz, Klaus. 1994. Forschungskonzeptionen der Wirtscftswissenschaft. 3rd. ed. Stuttgart: Schäfer-Poeschel.

Christensen, Ralph J. 1987. Das Problem des Richterrechts aus der Sicht der Strukturierenden Rechtslehre. Archiv für Rechts- und Sozialforschung LXXIII (75-92): .

Dahrendorf, Ralf. 1968. Values and Social Science: The Value Dispute in Perspective. Essays in the Theory of Society, Stanford, CAL: Stanford University Press, 1-18.

Dogan, Mattei, and Pahre. R. 1989. Fragmentation and recombination of the social science. Studies in Comparative International Development 24 (2): 2-18.

Dogan, Mattei. 1998. Political Science and the Other Social Sciences. In: A New Handbook of Political Science, edited by R. E. Goodin and H.-D. Klingemann. Oxford: Oxford University Press. 97-130.

Dunhoff, Jeffrey L, and Joel P. Trachtman. 1999. Economic Analysis of International Law. The Yale Journal of International Law 24: 1-59. 
Engel, Christoph. 1998. Rechtswissenschaft als angewandte Sozialwissenschaft. Preprints der Max Planck Projektgruppe 'Recht der Gemeinschaftsgüter' 1998 (1)

Esser, Josef. 1970. Vorverständnis und Methodenwahl in der Rechtsfindung.

Falk, Richard A. 1993. Remarks. Paper read at Teaching International Relations and International Organization in Internatinal Law Courses: Constructing the State-of-the Art- International Law Course, at Washington, D.C.

Friedman, Lawrence M. 1996. Borders: On the Emerging Sociology of Law. Stanford Journal of International Law 32: 65-90.

Goldsmith, Jack. 2000. Sovereignty, International Relations Theory and International Law. Stanford Law Journal 52: 959-986.

Goodwin-Gill, Guy. 1996. The Refugee in International Law, 2nd edition, Oxford: Clarendon Press.

Gould, Wesley L. 1987. Remarks. Proceedings of the 81st Annual Meeting of the American Society of International Law of the American Society of International Law, edited by American Society of International Law. Washington, D.C.: American Society of International Law. 383-385.

Guiraudon, Virginie. 2000. European Integration and Migration Policy: Vertical Policy-making as Venue Shopping. Journal of the Common Market Studies 38 (2): 251-271.

Hathaway, James C., ed. 1997. Reconceiving International Refugee Law, The Hague et al.: Nijhoff.

Holden, Matthew Jr. 2000. The Competence of Political Science: "Progress in Political Research" Revisted. Presidential Address, American Political Science Association, 1999. American Political Science Review 94 (1): 1-19.

Joerges, Christian. 1974. Das Rechtssystem der transnationalen Handelsschiedsgerichtsbarkeit. Zeitschrift für das gesamte Handelsrecht und Wirtschaftsrecht 138 (5/6): 549-568.

Joerges, Christian 2000, Wie sollte das Recht über seine Befolgung denken und aus der Politkwissenschaft lernen? Paper presented at a Workshop on Compliance at the European University Institute, Florence, February 28/March 12000.

Joyner, Christopher C. 1987. Crossing the Great Divide: Views from a Political Scientists Wandering in the World of International Law. In: Proceedings of the 81st Annual Meeting (Boston, $M A$,), edited by A. S. o. I. Law. Washington, D:C:: American Society of International Law. 385-391.

Keohane, Robert O. 1997. International Relations and International Law: Two Optics. Harvard Internatinal Law Journal 38 (2): 487-502.

King, Gary, /Keohane Robert O., and Sidney Verby. 1994. Designing Social Inquiry: Scientific Inference in Qualitative Reserach. Princeton: Princeton University Press.

Knetsch, Jack L. 1998. Law and Social Sciences: Reciprocal Influences and Opportunities. In: Law, Social Sciences and Public Policy, edited by A. Chin and A. Choi. Singapore: Singapore University Press.

Kratochwil, Friedrich V. 2000. How do Norms Matter? In: The Role of Law in International Politics. Essays in International Relations and International Law, edited by M. Byers. Oxford: Oxford University Press. 35-68.

Lavenex, Sandra. 1999a. The Europeanization of Refugee Policy: Between Human Rights and Internal Security, European University Institute (PhD thesis), Florence.

Lavenex, Sandra. 1999b. Safe Third Countries. Extending the EU Asylum and Immigration Policies to Central and Eastern Euope. Budapest: Central European University Press.

Marauhn, Thilo. 1998. A European Security and Defence Network - developing a framework of analysis for multilateral defence co-operation in Europe, in: J. Huru, O.-P. Jalonen, M. Sheehan (eds.), New Dimensions of Security in Central and Northeastern Europe, Tampere Peace Research Institute Research Report No. 83: 85-115.

Merton, Robert K. 1996. On Social Structure and Science. Edited and with an introduction by Piotr Sztompmka ed. Chicago: Chicago University Press. 
Müller, Friedrich. 1997. Juristische Methodik. Edited by R. Christensen. 7th rev. ed. Berlin: Duncker\&Humblot.

Neyer, Jürgen, Dieter Wolf, and Michael Zürn 1999, Recht jenseits des Staates. Bremen: Zentrum für Europäische Rechtspolitik and der Universität Bremen (ZERP).

Noll, Gregor. 1997. Prisoner's Dilemma in Fortress Europe: On the Prospects for Equitable Burden Sharing in the European Union, German Yearbook of International Law 40, 405-437.

Okruch, Stefan. 1999. Innovation und Diffusion von Normen: Grundlagen und Elemente einer evolutorischen Theorie des Institutionenwandels. Berlin: Duncker \& Humblot.

Sartori, Giovanni. 1969. From Sociology of Politics to Political Sociology. In: Politics and the Social Science, edited by S. M. Lipset. New York: Oxford University Press. 65-100.

Scharpf, Fritz W. 1997. Games Real Actors Can Play. Actor-Centered Institutionalism in PolicyResearch. Boulder, Co.: Westview Press.

Slaughter Burley, Anne-Marie. 1993. International Law and Internatinal Relations Theory: A Dual Agenda. American Journal of International Law 87: 205-239.

Slaughter, Anne-Marie, Andrew S. Tulumello, and Stephan Wood. 1998. International Law and International Relation Theory: A New Generation of Interdisciplinary Scholarship. American Journal of International Law 92 (3): 367-397.

Slaughter, Anne-Marie. 1995. International Law in a World of Liberal States. European Journal of International Law 6 (1995): 503-538.

Tamanaha, Brian Z. 1995. An Analytical Map of Social Scientific Approaches to the Concept of Law. Oxford Journal of Legal Studies 15 (4): 501-535.

Toope, Philip. 2000. Emerging Patterns of Governance and International Law. In: The Role of Law in International Politics. Essays in International Relations and International Law, edited by M. Byers. Oxford: Oxford University Press. .

UNHCR. 1979. Handbook on Procedures and Criteria for Determining Refugee Status, Geneva.

UNHCR. 1995. An Overview of Protection Issues in Western Europe: Legislative Trends and Positions Taken by UNHCR. European Series Vol.1 No. 3, September 1995, Geneva.

Weiler, Joseph H.H. 1993. Journey to an Unknown Destination: A Retrospective and Prospective of the European Court of Justice in the Arena of Political Integration. Journal of Common Market studies 31: 417-446.

Weiler, Joseph H.H. 1994. A Quiet Revolution. The European Court of Justice and Its Interlocutors. Comparative Political Studies 26: 510-534.

Young, Oran. 1992. Remarks. Proceedings of the 86st Annual Meeting of the American Society of International Law (International Law and International Relations Theory: Building Bridges). Washington, D.C.: American Society of International Law, 172-175.

Young, Oran. 1994. International Governance. Protecting the Environment in a Stateless Society. Ithaca and London: Cornell University Press. 


\section{Notes}

1 To be published in: Michael Bommes and Eva Moravska (eds.). Reflections on Migration Research: Constructions, Omissions, and Promises of Interdisciplinarity, California University Press. For critical and helpful comments comments we are grateful to Tanja A. Börzel, Michael Bommes, Kirsten Dauck, Christoph Engel, Adrienne Héritier, Sandra Lavenex, Leonor Moral Soriano and Stefan Okruch.

As the Treaty of Amsterdam has subordinated migration and refugee matters into the 'first' or 'Community' pillar of the European Union, we will use the expression 'European Community' instead European Union throughout the text. For a more sophisticated approach see Müller 1997.

“... as far as we are, we know more about politics than any other discipline” M. Holden Jr. in his presidential address of the American Political Science Association 1999, (Holden 2000). The extradition, expulsion and return of persons in danger of being tortured or ill-treated is forbidden under Art. 3 ECHR irrespective of whether the danger emanates from a non-governmental source or from the State. This has been confirmed by the European Court of Human Rights in several cases (Ahmed $v$ Austria, D. v United Kingdom, H.L.R. v France).

How such normative criteria function and influence national and European policies on refugees will be determined to a certain extent by legal factors, although not exclusively. In order to establish the legal factors, questions arise such as whether a particular state is applying a monistic or a dualistic regime in the adoption of international law or regarding how far certain international norms may be enforced by the courts of the State or even be reviewed by international courts or human rights bodies. This also means that certain international norms may have a more or less direct legal impact whereas others only rely on their appelative character.

The concept of temporary protection has been discussed in an interdisciplinary project under the direction of James Hathaway in a most stimulating manner, without, however, suggesting final solutions, cf. Hathaway 1997.

Für das Recht ist die "eigene Anwendungsgeschichte traditionell und bis heute auch praktisch sein wichtigstes Erkenntnisinstrument” (Engel 1998, 19f).

See Goldsmith 2000, 981-986 for other obstacles that impede a dissolution of boundaries between international law and international relations.

A positive analysis presents facts about "what has happened" or "what will happen". In contrast, an analysis is normative when it is based on value judgements involving a pre-established criterion. Statements of "what ought to be done" are normative.

11 More precisely, there are two distinct versions of the 'gap problem'. One version refers to the gap between state legal rules and what people in a community actually do, the second version refers to the gap 
between state legal rules and what legal institutions actually do (Tamanaha 1995, 512). Our interest is in the second version.

12 Neyer, Wolf and Zürn 1999; Joerges 2000. 